\title{
THE ROLE OF HALAL CERTIFICATION IN BUSINESS PERFORMANCE IN SELANGOR: A STUDY ON KOPITIAMS
}

\author{
ASNIDAR HANIM YUSUF \\ IDRIS OYEWALE OYELAKIN \\ SYADIYAH ABDUL SHUKOR \\ UMMI SALWA AHMAD BUSTAMAM \\ Faculty of Economics and Muamalat \\ Universiti Sains Islam Malaysia
}

\begin{abstract}
Halal certification plays a key role in food and beverages industry in Malaysia. This certification indicates that the food product is assured in terms of religious compliance, safety and hygiene. There is limited study conducted from the viewpoint of business owners and what benefit it can do in terms of their business development. This research was conducted to associate the role of Halal certification and business performance in four selected Kopitiams around Selangor from various categories; Muslim Halal certified, Muslim not Halal certified, non Muslim Halal certified and non Muslim not Halal certified. Business operators and consumers of the said Kopitiams were interviewed and all case studies were analyzed using descriptive and interpretive analysis. The findings are in line with theories used which are Resource Based View, Theory of Reasoned Action and Theory of Perceived Behavior. The outcome of the study concluded that Halal certificate does bring benefit in their business performance in terms of Islamic view, social contribution, financial capital and human capital. Halal certification is a motivation to gain religious benefit, customer satisfaction, provide more job opportunities and avoid social problems. In financial capital, it serves as an internal resource to boost sales and influence customers' purchasing decision. For human capital, Halal certificate can increase skill and development of the companies' human resources.
\end{abstract}

Keywords: Business Performance (BP), Halal Certification (HC), Resource Based View (RBV), Theory of Perceived Behavior (TPB), Theory of Reasoned Action (TRA). 


\section{Introduction}

Halal certification in Malaysia has many benefits in terms of higher market segment (Liow, 2012; Husain et al., 2012; Said \& Elangkovan, 2013), hygiene and safety (Syed Marzuki et al., 2012; Ahmad et al., 2013) and potential to gain interest from Muslim tourist all over the world to come to Malaysia (Ab Rahman Ilyia et al., 2011; Syed Marzuki et al., 2012).

In Islamic point of view there are studies that highlighted that growth in business is not in terms of materials (Vargas-Hernandez \& Noruzi, 2010; Muhammad et al., 2013; Faizal et al., 2013). But the growth concept of Islamic business stressed on the balanced satisfaction of material and spiritual needs (Muhammad et al., 2013). Another aspect of business performance is defined as social contribution. According to Beekun (2004), the ability of a company to provide social contribution to various parties such as its employees and community is used as an indicator of how the business is accepted by the society. Again, business performance is multidimensional in nature. Therefore, to capture different dimensions of business performance, a combination of financial performance and growth was suggested to be used. The growth is used as a measure of performance which may be more accurate than accounting measures of financial performance (Wiklund \& Shepherd, 2005). Howard (2006) outlined that business growth is defined by the amount of sales, profit, geographic expansion and size of workforce. Finally, business performance can also be measure in terms of human capital, Sherman (2007) defined business growth in three different pillars; human capital, financial capital and intellectual capital. According to Carter and John-Evans (2006), most research discussed the business growth in terms of employment because of the interest of public policy maker in facilitating growth in employment activity. Kaloo (2010) further explained growth as increase in number of employees, capital employed, number of locations and sales revenue.

Halal certification has many benefits in different industry such as the food and service industry. However, in this study we will concentrate on Kopitiam in the food industry. Kopitiam means coffee shop in local Chinese dialect in Malaysia and Singapore. According to Lai (2010), initially when the Kopitiam business started in 1950's in Klang Valley, it was meant to serve food and drink to the local community. Over the years, Kopitiam are becoming more popular spots for community to catch up with one another. Recently, new breed Kopitiam has emerged in Malaysia and become more popular eatery for people to stop by for good food and catch up with families and 
friends. The new concept of Kopitiam eatery combines both traditional and modern ambience in the restaurant (UK Essays, 2015).

However, there is limited study that discuss on what benefit Halal certificate can do to business performance. Business owners are usually interested to invest in activities that bring direct benefit to their profitability and development of their business (Yusuf et al., 2016). The focus of this study is to explore the benefit of Halal certificate to business performance using the selected food premise. The main objective is to understand the role of Halal certificate in the Kopitiams business around Selangor and to find out if by having Halal certificate would bring good benefit to the business or not. This study will further aim to understand the role of Halal certification in business performance in terms of Islamic view, social contribution, financial capital and human capital. To achieve this, the research finds the relationship between business performance and Halal certification or Halal implementation in food outlet. The research took the approach of qualitative study to gain more insight and gain information on experiences of the business owners of Kopitiams in Selangor. The method chosen to get the information needed is case study for four selected Kopitiams.

\section{Literature Review}

The term "Halal" in products is an overall concept to encourage Muslims to seek products that promote Islamic compliance and cleanliness. This makes the products (Halal product) to be seen as safe for consumption, produced in clean environment and used as benchmark for quality (Wan Omar et al., 2008).

Halal certification on the other hand, according to Machfud et al. (2011) is the examination of food process from its preparation, slaughtering, cleaning, handling, disinfecting, storing, transportation and management practises. Business wise, Halal certification process involves the overall stages "from farm to table". To ensure that the Halal concept is well maintained and monitored by the expert in the field, the Department of Islamic Development Malaysia (Jabatan Kemajuan Islam Malaysia - JAKIM) and state religious councils such as Department of Islamic Development of Selangor (Jabatan Agama Islam Selangor - JAIS) have been appointed by the government to handle the applications, certifications, enforcement and monitoring the implementation of Halal certification. 
There are three theories used as based for this research; Resource Based View (RBV), Theory of Perceived Behavior (TPB) and Theory of Reasoned Action (TRA). According to Wernerfelt (1984), the method to analyze firm's growth strategy is from the resource side and not on the product side. The growth strategy is done by exploiting the current resources and developing the new ones. Resource Based View as mentioned by Barney (1991) means the firm's internal characteristic and performance will determine that the firm achieves sustained competitive advantages. Firm's resources includes of three categories; physical capital resources (plant, equipment and others), human capital resources (training, experience, intelligent and others) and organizational resources (reporting structure, planning, controlling, coordinating systems among others). The firm's resources must be heterogeneous and immobile. According to Dube et al. (2016), Halal certificate system is used as resource-based view of firm internationalization. In the study which compared two Halal certification systems between Malaysia and China, the paper discussed that Halal certificate in a firm meet the characteristic and provides competitive advantage to the firm in their internationalization. The same concept is taken into consideration in determining if Halal certificate can be considered as a resource to improve business performance in the selected Kopitiams in this study.

Whereas in the area of consumer's perceptions and behaviors, the theory used in order to support the condition is Theory of Reasoned Action (TBA) and Theory of Perceived Behavior (TPB). The Theory of Reasoned Action is a model that is used to predict the intention to perform a behavior based on a person's attitudinal and normative beliefs (Southey, 2011). In a study conducted by Othman \& Hashim (2010), religion has been identified as a major force to influence an individual's buying behavior and shaping food choice. In the paper, the researchers found that in Muslim community, their beliefs, commitments and practices in the religion of Islam is a major factor that shapes their behavioral intention towards their decision during purchasing food products. The Halal status which is judged by Halal certification and logo are looked upon by Muslim consumers according to Samori et al. (2014). According to the study, Muslim consumers consider Halal logo as a signal that the food premise is considered permissible and the Halal status is guaranteed. Apart from the Muslim society, there is also demand from non-Muslim society in Malaysia on Halal certified products. In a study conducted by Quantaniah and Nureina (2013), non Muslim consumers who are health conscious prefer the choice of Halal certified premises compared to the ones without it because Halal certified means the premises practice safety and hygiene. 


\section{Research Methodology}

The technique used for data collection in this study is in-depth interview with Kopitiam business owners, managerial staff and operational staff.

The instruments used are semi structured open ended questions so that the respondents (Kopitiam business owners, managerial staff and operational staff of the Kopitiam) can focus on issues been raised by them instead of being restricted to researcher's questions (Barbour, 2013). Purposive sampling was also used to select the case study participants. This was used because there was a need to analyze certain set of groups in order to answer the questions raised in the study (Koerber \& MacMichael, 2008). Reason being that the participants' organizations need to have certain characteristics and qualities that will be discussed further in this section. The contrast types of criteria were also used to examine the differences in the outcome of this study. This contrast type of criteria is called polar sampling. Polar sampling is used when the study needs to demonstrate the differences between opposite or contrast characteristic (Eisendhart 1989; Eisendhart \& Graebner 2007). To effect that in this study, it is noted that, while other characteristic of selecting the Kopitiams are the same, two of the characteristics are contrast to each other; which are Halal certification status of the Kopitiam and the religion of the business owners.

The characteristic of the four Kopitiams selected in this study, K1, K2, K3 and K4 are shown as below Table 1

List of kopitiams and their characteristics

\begin{tabular}{lcccc}
\hline Kopitiam & K1 & K2 & K3 & K4 \\
\hline Business line & Kopitiam & Kopitiam & Kopitiam & Kopitiam \\
$\begin{array}{l}\text { Year of } \\
\text { establishment }\end{array}$ & 2008 & 2011 & 2006 & 2005 \\
$\begin{array}{l}\text { Type of business } \\
\text { ownership }\end{array}$ & Private Ltd Co & Private Ltd Co & Private Ltd Co & Private Ltd \\
Sales performance & $<$ RM 3M & $<$ RM 3M & $<$ RM 3M & $<$ Co 3M \\
& annually & annually & annually & annually
\end{tabular}


No of employee in

each outlet

Halal certificate

Owner religion
20

Yes

Muslim
16

No

Muslim
20

Yes

Non-Muslim Non-Muslim

The participants in the interview were business owners, restaurant managers, administrative staff, front workers (waiter/waitresses) and kitchen staff which are related to gain the information needed in the research. In order to gain in-depth information, it is required to get the information listed in the check sheet needed from the respondents, the method used was interview with the respondents by using semi structured and open ended check sheet.

In this study, focus groups were used during the interview sessions for business operators and consumer groups which include the whole team from the selected Kopitiams. Among the departments required to participate in the data collection were business owners, top managements, managerial staff and also operation staff such as front line staff (waiter/waitress) and kitchen staff to gain information on their views and opinions of Halal certification role in their business performance.

\section{Analysis and Discussion}

This section will discuss on the result, analysis and discussions done after conducting in-depth interviews with business operators and consumers of each Kopitiams.

\section{Role of Halal Certification in Islamic View}

As explained in Research Methodology, among the four Kopitiams chosen in this study, only two of them are owned by Muslims. For instance, in the interview sessions for Islamic view, only K1 and K2 Kopitiams were involved in answering this part. Table 2 below, shows the two Muslim Kopitiams, $\mathrm{K} 1$ and K2 characteristic consistency with the discussions in Vargaaz-Hernandez and Noruzi (2010) and Faizal et al. (2013) that mentioned Muslim business operators ultimate goal, which is to achieve Allah's blessing. In these findings, it is clear that both K1 and K4 Kopitiam believed that Halal certification is important to be implemented in their food premises as it will bring benefits in business performance in terms of Islamic value (spiritual) and not only the physical value. That is in line with the discussion made by Mohd Yunus et al. (2010) that the main goal for business is to gain Allah's blessings and usage of business as a medium of practicing good values. In summary, it can be said 
that all case studies in $\mathrm{K} 1$ and $\mathrm{K} 2$ Kopitiam agreed that Halal certificate has role on business performance in terms of fardhu kifayah (communal obligation), barakah (Allah's blessing), tayyib (clean and purity), rizq (sustenance) and rahmah (Allah's compassion) in their business premises.

Table 2

Summary of role of Halal certification in Islamic view

\begin{tabular}{|c|c|c|c|c|c|}
\hline Case studies & $\begin{array}{c}\text { Fardhu } \\
\text { kifayah } \\
\text { (communal } \\
\text { obligations) }\end{array}$ & $\begin{array}{l}\text { Barakah } \\
\text { (Allah's } \\
\text { blessing) }\end{array}$ & $\begin{array}{c}\text { Tayyib } \\
\text { (clean \& } \\
\text { pure) }\end{array}$ & $\begin{array}{c}\text { Rizq } \\
\text { (sustenance) }\end{array}$ & $\begin{array}{c}\text { Rahmah } \\
\text { (Allah's } \\
\text { compassion) }\end{array}$ \\
\hline K1 & $\begin{array}{l}\text { Provide Halal } \\
\text { food }\end{array}$ & $\begin{array}{l}\text { Reflect in } \\
\text { personal lives }\end{array}$ & $\begin{array}{l}\text { Good work } \\
\text { environment } \\
\text { Kind } \\
\text { employers }\end{array}$ & $\begin{array}{l}\text { Increase rizq } \\
\text { because } \\
\text { customers' } \\
\text { confidence }\end{array}$ & $\begin{array}{l}\text { Sons want to } \\
\text { be involved in } \\
\text { same business }\end{array}$ \\
\hline $\mathrm{K} 2$ & $\begin{array}{l}\text { Provide Halal } \\
\text { food }\end{array}$ & Important & $\begin{array}{l}\text { Islamic work } \\
\text { environment } \\
\text { Employer } \\
\text { allow to } \\
\text { perform solah } \\
\text { (prayer) }\end{array}$ & $\begin{array}{l}\text { Increase rizq } \\
\text { that is } \\
\text { barakah }\end{array}$ & - \\
\hline
\end{tabular}

\section{Role of Halal Certification in Social Contribution}

Apart from the monetary success, ethical business practitioners also seek satisfaction through their contribution to the society (Lev et al., 2006). Alazzabi and Selamat (2010) in their research mentioned that social responsibility include doing charity, providing acceptable wages to the employees and giving them the environmental protection. In this study, it has been found that Halal certification has brought success to companies, to the point where companies can contribute back to the society by doing charitable activities. This is a way of measuring the business performance in terms of other values instead of the conventional way of measuring the success of a business through monetary and physical achievement. The categories of social contributions gathered from all four Kopitiams are as 
follows; charitable deed, provide employment, provide better work environment/business system and customer satisfaction.

It was also found that there are different reasons of conducting charitable deeds in Muslim and nonMuslim business owners. The derivation of conducting charitable deeds in Muslim owners (K1 and K2 Kopitiams) are to please Allah SWT while the non-Muslim owners (K3 and K4 Kopitiams) expect to contribute something to the society that they belong to. However, all four Kopitiams agree that Halal certification is a requirement to ensure customer's satisfaction because of religious requirement to the Muslim consumers and the aspect of safety and hygiene in general. The finding of the study is in line with Tan et al. (2012) that says it is a responsibility of a business organization to provide Islamic compliant service to customers. The implementation of Halal concept is also viewed as service quality to ensure the level of satisfaction required by the Kopitiam's customers. The same scenario was discussed by Singh (2013) which mentioned that the service quality will improve customer satisfaction in the service industry. The finding details of the role of Halal certification in terms of social contribution for K1, K2, K3 and K4 Kopitiam is shown below in Table 3.

All four Kopitiams agree that Halal certification and implementation can help their business to gain business performance in terms of social contribution according to their perceptions which are charitable deed, provide employment, provide better working environment and business system and finally customers' satisfaction.

Table 3

Summary of role of Halal certification in social contribution

\begin{tabular}{cllll}
\hline $\begin{array}{c}\text { Case } \\
\text { studies }\end{array}$ & Charitable deed & \multicolumn{1}{c}{$\begin{array}{c}\text { Provide } \\
\text { employment }\end{array}$} & $\begin{array}{c}\text { Better work } \\
\text { environment } / \\
\text { business system }\end{array}$ & $\begin{array}{c}\text { Customer } \\
\text { satisfaction } \\
\text { (Halal \& clean) }\end{array}$ \\
\hline K1 & Orphanage & Employment to & Happy work & - \\
& Al Quran class & local youth & environment & \\
& & Part time jobs for & \\
& & & \\
& & & \\
& &
\end{tabular}




\begin{tabular}{|c|c|c|c|c|}
\hline & $\begin{array}{l}\text { Built musolla \& } \\
\text { contribution in } \\
\text { Cambodia, Indonesia }\end{array}$ & & & \\
\hline $\mathrm{K} 2$ & $\begin{array}{l}\text { Discounts for buka } \\
\text { puasa dinner (orphans } \\
\text { and students) }\end{array}$ & $\begin{array}{l}\text { Job opportunities } \\
\text { to local people } \\
\text { Avoid social } \\
\text { problems }\end{array}$ & - & $\begin{array}{l}\text { Affordable, Halal } \\
\text { \& clean } \\
\text { Dining } \\
\text { experience to } \\
\text { local people } \\
\text { (new ambience } \\
\text { and variety of } \\
\text { food types) }\end{array}$ \\
\hline K3 & - & $\begin{array}{l}\text { K3 Express } \\
\text { Micro Franchise }\end{array}$ & $\begin{array}{l}\text { Better standard of } \\
\text { work } \\
\text { Better suppliers }\end{array}$ & $\begin{array}{l}\text { Muhibbah } \\
\text { concept } \\
\text { Halal for Muslim } \\
\text { consumers }\end{array}$ \\
\hline K4 & - & $\begin{array}{l}\text { Work } \\
\text { opportunity for } \\
\text { Halal related jobs } \\
\text { Job opportunities } \\
\text { for others }\end{array}$ & - & $\begin{array}{l}\text { Halal for Muslim } \\
\text { consumers }\end{array}$ \\
\hline
\end{tabular}

\section{Role of Halal Certification in Financial Capital}

As regard of business performance in financial capital, there are various information gained from the interviews of the four Kopitiams. Mainly, all four Kopitiams define financial capital in two terms; 1) sales performance, geographical or business expansion, 2) consumer patronage. Based on the findings, $\mathrm{K} 1$ and $\mathrm{K} 2$ agree that Halal certification enhance business growth and increase market share as mentioned in studies conducted by Shafie and Othman (2004), Liow (2012) and Abdul et al. (2013). However, from findings of all four Kopitiams, it can be understood that K1and K2 Kopitiam respondents said that in their situation, Halal certificate brings positive impacts on the sales 
performance, but it must be noted that K3 and K4 Kopitiam respondents thought otherwise. Although both K3 and K4 Kopitiam did not say that Halal certificate brought negative impacts, they only thought that there is no direct impact or sales increase due to Halal certification. This opinion is seconded by a paper by Che Omar \& Anas (2014) that mentioned only $25 \%$ of the Halal certificate owners gained increase in their sales performance after obtaining and displaying the certification or $\log$ at their premise. The increase gained was also considerably low, only about 5-7\%. However, it must be considered that the sample size for this study is small and cannot be used as generalization to the whole industry to make a conclusion. Furthermore, all four Kopitiams refused to reveal sales records as they consider the information as confidential, hence the actual sales collections are not made known to this study to compare the effect. This situation was also highlighted by Carter \& JohnEvans (2006) that mentioned the industries are reluctant to disclose any data of their sales and profits causing difficulties in measuring business growth and performance. Due to this, the current studies mostly focus on employment for the measurement of business performance.

The findings on consumer patronage also showed that all Muslim consumers from the four focus groups agreed that Halal certificate is an important factor that they consider before entering food premises, because Halal is an obligation in their religion with other reasons of consuming food without doubt. The behavior shown in this finding is consistent with Theory of Reasoned Action (TRA) and Theory of Planned Behavior (TPB) which are discussed in Hanzaee and Ramezani (2011) and Zailani et al. (2011). Both papers discussed that the belief of consumer will influence their food consumption and buying decisions.

In conclusion, $\mathrm{K} 1$ and $\mathrm{K} 2$ Kopitiam agreed that Halal certification plays a role in business performance in terms of sales performance whereas K3 and K4 Kopitiam mentioned that it does not increase the sales collection. However, K3 Kopitiam informed that during the Malaysia's economic downturn and price hike, Halal certification helped them not to lose customers and maintain their sales collection. As for K4 Kopitiam, the participants mentioned that Halal certification attracts new customers and new business ventures. In terms of business expansion of business performance, all four Kopitiams in this study agreed that Halal certification brings benefits in the expansion of the business. The finding of role of Halal certificate in financial capital is shown as below in Table 4 . 
Table 4

Summary of role of Halal certification in financial capital

\begin{tabular}{|c|c|c|}
\hline $\begin{array}{c}\text { Case } \\
\text { studies }\end{array}$ & Sales performance & Geographical expansion \\
\hline K1 & $\begin{array}{l}\text { Play important role } \\
\text { Obvious boost and increase in sale } \\
\text { HC as promotion and marketing strategy } \\
\text { Heavy traffic of customers } \\
\text { Tabung Haji project }\end{array}$ & $\begin{array}{l}\text { Expanded from KLIA - } 2 \text { branches }- \text { new to } \\
\text { open in Wangsa Maju } \\
\text { Opportunities of oversea expansion } \\
\text { Franchise inquiry }\end{array}$ \\
\hline $\mathrm{K} 2$ & $\begin{array}{l}\text { Increase in customers and sales } \\
\text { Good marketing tool }\end{array}$ & $\begin{array}{l}\text { Expansion of restaurant size \& new } \\
\text { departments } \\
\text { Future plans to expand to other places }\end{array}$ \\
\hline K3 & $\begin{array}{l}\text { No direct increase in sales but } \mathrm{HC} \text { keeps } \\
\text { maintain the incoming no of customers and } \\
\text { avoid sales drop }\end{array}$ & $\begin{array}{l}\text { Expansion in Indonesia ( } 32 \text { branches all over) } \\
\text { Future plan - Middle East } \\
\text { Expansion of new production line (products- } \\
\text { white coffee, instant food) } \\
\text { Micro credit franchise scheme } \\
\text { Kopitiam franchise expansion }\end{array}$ \\
\hline K4 & No significant increase in sales & $\begin{array}{l}\text { Easier to open new branch - customer's } \\
\text { confidence of Halal }\end{array}$ \\
\hline & Malay Muslim customers increase & $\begin{array}{l}\text { Expansion of branches (no more franchise } \\
\text { because bad experience) }\end{array}$ \\
\hline
\end{tabular}

\section{Role of Halal Certification in Human Capital}

In this research, two aspects of human capital are identified in order to check if Halal certificate has any role in business performance or not. The first one is number of employee and the second one is skills and development of the employees. All the four Kopitiams mentioned that number of employees increased after implementation of Halal certificate because it results in the expansion of their business 
branches or franchises. Number of employees is among the well discussed forms of business performance because the data is easily available at business organizations (Carter \& John-Evans, 2006). As for the skills and development, all four Kopitiams agreed that Halal certification brings benefits in business performance in terms of skills and knowledge of the customers. K4 Kopitiam gave example of how skills and knowledge of the workers from purchasing side and kitchen are important to avoid contamination in the whole food process. It is highly important to ensure the state of good skills and knowledge among the employees to protect Halal integrity (Ab Talib \& Mohd Johan, 2012). Due to awareness of that, all Kopitiams except K2 have their own training unit to ensure enough training is provided in order to protect Halal integrity, avoid contamination and noncompliance. Skills and development of employees will lead to innovations and produce higher quality products.

In conclusion, for all four case studies that have been interviewed, all respondents agree that Halal certification or implementation does play a role in increasing their business performance in terms of human capital for number of employees and skills and development. Table 5 shows the result of role of Halal certification in human capital in this study.

Table 5

Summary of Role of Halal Certification in Human Capital

\begin{tabular}{|c|c|c|}
\hline $\begin{array}{l}\text { Case } \\
\text { studies }\end{array}$ & Employee numbers & Skill \& development \\
\hline K1 & $\begin{array}{l}\text { Increase when branch expanded - } \\
\text { must control limit } \\
\quad \text { - Currently } 18 \text { person/outlet }\end{array}$ & $\begin{array}{l}\text { Food handling course } \\
\text { HOD training } 1 / \text { week or } 1 / \text { fortnight } \\
\text { Religious class for employees } 1 / \text { month or } 2 / \text { month } \\
\text { Knowledge increase (purchasing activities, customers question) } \\
\text { Helped employee to be independent }\end{array}$ \\
\hline $\mathrm{K} 2$ & $\begin{array}{l}\text { Employees increased } \\
\begin{aligned}- & \text { Chef } 1 \rightarrow 5 \text { persons } \\
- & \text { Floor staff (to cover } 2 \text { lots) } \\
\text { - } & \text { Catering staff (part timers) }\end{aligned}\end{array}$ & $\begin{array}{l}\text { Chef cooking skill (variety of food) } \\
\text { Practical students increased knowledge \& skill in business } \\
\text { experience and culinary in the kitchen }\end{array}$ \\
\hline
\end{tabular}


- Central kitchen staff

\begin{tabular}{|c|c|c|}
\hline & - Central kitchen staff & $\begin{array}{l}\text { Implementation of Halal - new work skills for some staff (new } \\
\text { staff, transferred staff from construction office) }\end{array}$ \\
\hline & & Halal food handling by JAIS \\
\hline & & $\begin{array}{l}\text { OJT on Halal food purchasing, food preparation, front line } \\
\text { serving etc. }\end{array}$ \\
\hline & & HC apply on their own - staff to understand better about Halal \\
\hline \multirow[t]{7}{*}{ K3 } & Increase of manpower - branch \& & Employee skill improve, better business operation \\
\hline & franchise & Non-Muslims learnt about Halal concept, awareness \\
\hline & & JAKIM Halal training included non-Muslim as well \\
\hline & & Appoint Halal officers to handle JAKIM matters \\
\hline & & Kitchen staff - learnt type of Halal raw materials \\
\hline & & Planning to make skill level for employees \\
\hline & & $\rightarrow$ Training on Halal- extra cost to the operation \\
\hline \multirow[t]{9}{*}{ K4 } & Employee number increase with & Halal cert also covered HACCP - help increase staff knowledge \\
\hline & branch expansion & \& skill \\
\hline & & Comprehensive training system \\
\hline & & - $\quad$ Supervisor \& manager once / 2 weeks \\
\hline & & - $\quad$ Normal staff every quarterly \\
\hline & & - Staff meeting in every outlet \\
\hline & & - External training for food safety \\
\hline & & - Compulsory course for new restaurant staff \\
\hline & & - $\quad$ HACCP, Halal, 6 service steps \& others \\
\hline
\end{tabular}

Based on the discussions above, Halal certification or implementation plays a role in increasing their business performance in terms of Islamic view, social contribution, financial capital and human capital as shown in framework in Figure 1 below. 


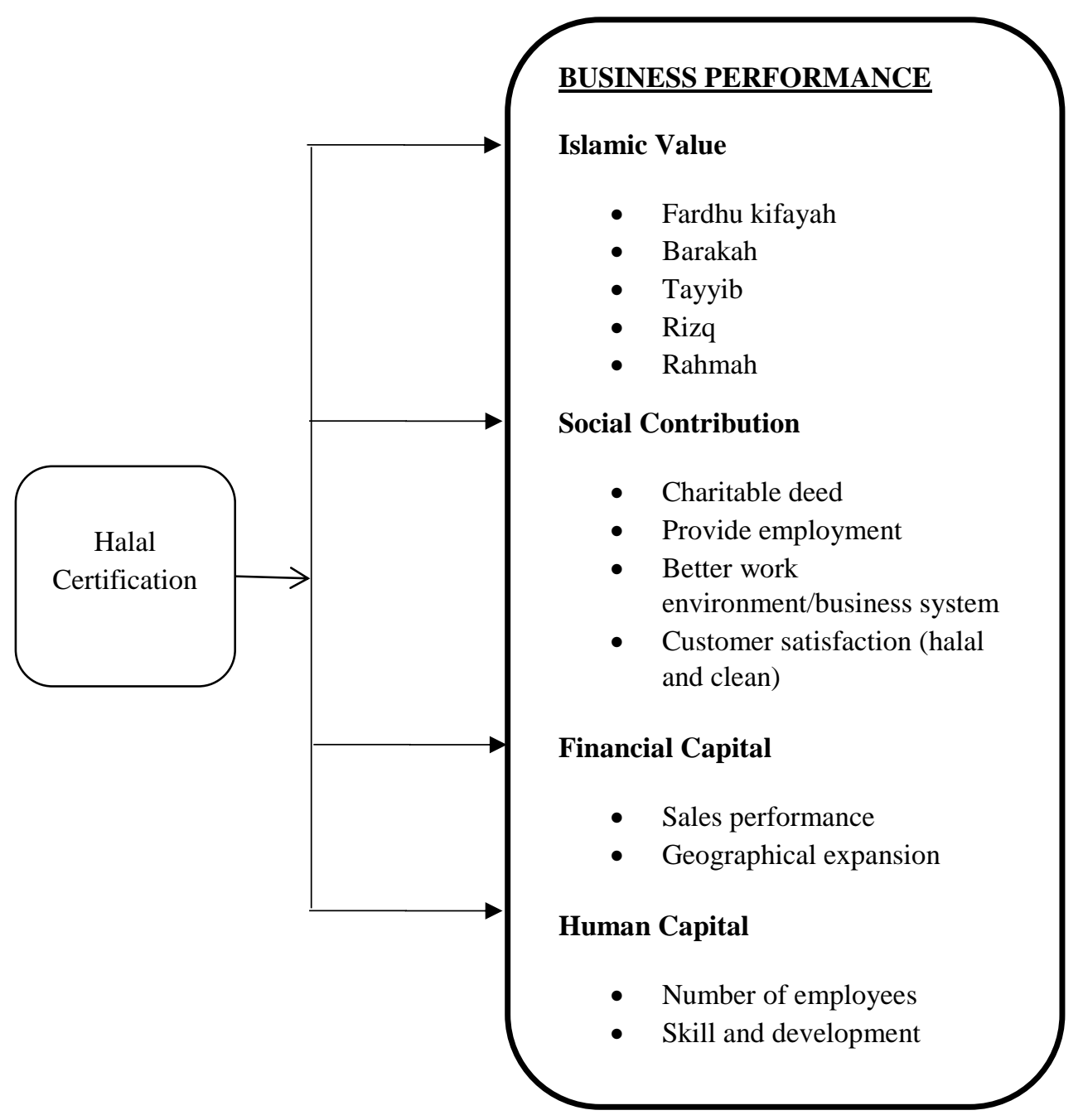

Figure 1. Framework of the role of Halal certification in business performance 


\section{Conclusion}

In conclusion, for all four case studies; K1, K2, K3 and K4 Kopitiams' respondents that have been interviewed, all respondents agree that Halal certification or implementation does play a role in increasing their business performance in terms of Islamic view, social contribution, financial capital and human capital. There are four areas of contribution and implication in this study. They are theory and methodology, policy, practice and social issues.

The contribution of the theory and methodology on the business operators' side was related to Resource Based View (RBV), which mentioned that a business needs different resources to begin and expand its operation. The finding of this study has added to the Resource Based Theory that Halal certificate is one of the resources to help a business during their start up and expansion of their operation. Also, based on Theory of Reasoned Action (TRA) and Theory of Reasoned Behavior (TRB), the study was conducted to check if their opinions on the importance of Halal certificate, perception towards Halal certificate and purchase decisions are based on their religious beliefs and the norms of their surrounding society (Southey, 2011; Othman \& Hashim, 2010). The result of the interviews showed that the importance of the Halal certificate was viewed differently from respondents of Muslim and non-Muslim. All of the Muslim respondents agreed that Halal certificate is very important because of their religious obligations and based on the teaching of Islam that teaches the importance of finding a Halal source in their food intake and their daily activities.

The policy aspect of the research findings, shows that all respondents from business operators and consumers side of four Kopitiams involved are well aware of the Halal concept, implementation and certification. It is very important to keep on educating the business operators or consumers through government promotions and campaigns. The findings gained in this study is hoped to attract more business practitioners to start applying for the Halal certificate.

On the practice side, the research was aimed to help encouraging Malaysian's restaurant business practitioners to apply for Halal certification to ensure Halal in religious view and good food quality, while at the same time help them to increase their business performance. This study helps to bring awareness and motivation on the importance of Halal certification and implementation. 
As regards of the social issue, findings show that Halal certification helps to provide more job opportunities and avoid social problems among the local community.

Finally, for future study, it is recommended to include other types of restaurants in Malaysia since this study was only on Kopitiam business. There is only one type of Halal certificate for all categories of food outlets. It is recommended to conduct further study on the relevance of introducing Halal certificate standard according to type and size of businesses. Since this study only covers food operators in Selangor, it is also recommended for future research to cover the whole Malaysia and also compare the experience and practices in other parts of the country.

\section{REFERENCES}

Ab Rahman Ilyia, N., Salleh, R., Ab Rahman, S., \& Mat Hashim, D. (2011). Factors Contributing to Non Compliance of the Halal Standard among Restaurant Operators in Malaysia. 2nd International Conference on Business, Economics and Tourism Management. IPEDR. 24. IACSIT Press, Singapore.

Ab Talib, M. S., \& Mohd. Johan, M. R. (2012). Issues in Halal Packaging: A conceptual paper. International Business and Management, 5(2), 94-98.

Abdul, M., Ismail, H., \& Mustapha, M. I. (2013). Halal Food Certification: Case of Malaysian SME Entrepreneurs. China-USA Business Review, 12(2), 163-173.

Ahmad, N. A., Tunku Abaidah, T. N., \& Abu Yahya, M. H. (2013). A Study on Halal Food Awareness among Muslim Customers in Klang Valley. 4th International Conference on Business and Economics Research Proceeding.

Alazzabi, M. S., \& Selamat, M. H. (2010). The relationship between Islamic cultural values and corporate social accountability: Malaysian Muslim accountants. Malaysia Management Journal, 14, 17-31.

Barbour, R. (2013). Introducing qualitative research. A students guide (2nd Ed.). California: Sage Publications. 
Barney, J. (1991). Firm resources and sustained competitive advantage. Journal of Management. $17(1), 99-120$.

Beekun, R. I. (2004). Islamic business ethics. New Delhi: Goodwork Books. 38-41.

Carter, S., \& Jones-Evans, D. (2006). Enterprise and small business. Principles, practise and policy. (2nd Ed.). Essex: Prentice Hall, Financial Times.

Che Omar, M. Z., \& Anas, T. (2014). Challenges and marketing strategies of halal products in Malaysia. Kuching: International Conference on Business and Economic Research Proceeding. 5.

Dube, F. N., Zhao, H., Yang, H., \& Huang, L. (2016). Halal certification system as a resource for firm internationalisation: Comparison of China and Malaysia. International Journal of Asia Pacific Study, 12(1), 125-141.

Eisenhardt, K. (1989). Building theories from case study research. Academy of Management Review, 14(4), 532-550.

Eisenhardt, K., \& Graebner, M. E. (2007). Theory building from cases. Opportunities and challenges. Academy of Management Journal, 50(1), 25-32.

Faizal, P. R. M., Ridhwan, A. A. M., \& Kalsom, A. W. (2013). The enterpreneurs characteristic from Al-Quran and Al-Hadis. International Journal of Trade, Economics and Finance, 4(4), 191196.

Hanzaee, K. H., \& Ramezani, M. R. (2011). Intention to halal products in the world markets. Interdisciplinary Journal of Research in Business, 1(5), 1-7.

Howard, J. (2006). Small business growth: Expansion of the workforce. Academy of Enterpreneurship Journal, 12(2).

Husain, R., Abd Ghani, I., Mohammad, A., \& Mehad, S. (2012). Current practises among halal cosmetics manufacturers in Malaysia. Journal of Statistical Modelling and Analytic, 13(1), 46-51.

Kaloo, U. (2010). Managing small enterprises. Petaling Jaya: Golden Books Centre. 
Koerber, A., \& MacMichael, L. (2008). Qualitative sampling methods. A primer for technical communicators. Journal of Business and Technical Communications, 22(4), 454-473.

Lai, A. E. (2010). The Kopitiam in Singapore. An evolving story about migration and cultural diversity. Asia Research Institute. Working Paper Series No. 132.

Lev, B., Petrovits, C., \& Radhakrishnan, S. (2006). Is doing good, good for you? Yes. Charitable Contributions Enhance Revenue Growth. New York University Stern School of Business.

Liow, R. (2012). Marketing halal, creating new economy, new wealth. Petaling Jaya: MPH Group Publishing.

Machfud, A., Dahlan, A., Khatib, J., \& Ahmed, A. (2011). Collaboration, wealth and value creation, SME's halal products communities and information systems. International Journal on New Computer Architecture and Their Applications (IJNCAA). The Society of Digital Information and Wireless Communications, 1(2), 510-518.

Mohd. Yunus, A., Wan Chik, W. M. Y., \& Mohamad, M. (2010). The concept of halalan tayyiba and its application in products marketing: A case study at Sabasun HyperRuncit Kuala Terengganu, Malaysia. International Journal of Business \& Social Science, 1(3).

Muhammad, M. Z., Ismail, A., Abdullah, A., Redzuan, R., \& Muhamad, S. (2013). The concept of business ethics in Islamic perspective: An introductory study of Small and Medium Enterprises (SMEs). Enterpreneurship Vision 2020. Innovation, Development, Sustainability and Economic Growth.

Othman, M. N., \& Hashim, A. H. (2010). Consumer perception and behavior towards halal food consumption. International Conference on Islamic Marketing \& Branding, Exploring Issues and Challenges, 1-17.

Quantaniah, N., \& Nureina, N. S. (2013). Selecting halal food: A comparative study of the Muslim and Non Muslim Malaysia student consumer. $2^{\text {nd }}$ International Conference on Technology Management, Business \& Enterpreneurship.

Said, M. M., \& Elangkovan, K. (2013). Halal label and ethics of business: An analytical view from producers. Australian Journal of Basic and Applied Science, 7(6), 613-621. 
Samori, Z., Ishak, A. H., \& Kassan, N. H. (2014). Understanding the developement of Halal Food Standard: Suggestion for Future Research. International Journal of Social Science \& Humanity, 4(6), 4-8

Shafie, S., \& Othman, M. N. (2004). Halal certification: An international marketing issues and challenges. Malaysia standardization for halal food, standard and quality new, 11(4), 9.

Sherman, A. (2007). Grow fast grow right. USA: Kaplan Publishing.

Singh, D. (2013). A comparative study of an Indian Public vs Private Bank. Malaysia Management Journal, 17, 59-75.

Southey, G. (2011). The theories of reasoned action and planned behavior applied to business decisions: A selective annotated bibliography. Journal of New Business Ideas and Trends, 9(1), 43-50.

Syed Marzuki, S. Z., Hall, C. M., \& Ballantine, P. W. (2012). Restaurant Manager Perspective on Halal Certification. Journal of Islamic Marketing, 3(1), 47-58

Tan, M. I. I., Razali, R. N., \& Husny, Z. J. (2012). The adoption of halal transportations technologies for halal logistics service providers in Malaysia. International Journal of Mechanical, Aerospace, Industrial and Mechatronics Engineering, 6(33), 16-23

UK Essays. (2013, November). UK Essays: Exploratory study of kopitiam business marketing essay. Retrieved from http://www.ukessays.com/essays/marketing/exploratory-study-of-kopitiambusiness-marketing-essay.php?cref $=1$

Vargas-Hernandez, J. G., \& Noruzi, M. R. (2010). An exploration of the affects of Islamic culture on enterpreneurial behavior in Muslim countries. Asian Social Science, 6(5), 120-128

Wan Omar, W. M., Muhammad, M. Z., \& Che Omar, A. (2008). An analysis of the Muslim consumers' attitude towards halal food products in Kelantan. Paper presented at ECER Regional Conference 2008, UiTM Kelantan.

Wernerfelt, B. (1984). A Resource-Based View of the Firm. Strategic Management Journal, 5(2), 171-180. 
Wiklund, J. \& Shepherd, D. 2005. Enterpreneurial orientation and small business performance: A configurational approach. Journalof Business Venturing, 20, 71-91.

Yusuf, A. H., Abdul Shukor, S., \& Ahmad Bustamam, U. S. (2016). Halal certification vs business growth of food industry in Malaysia. Journal of Economics, Business and Management, 4(3), 247-251.

Zailani, S., Omar, A., \& Kopong, S. (2011). An exploratory study on the factors influencing the non compliance to halal among hoteliers in Malaysia. International Business Management,5(1), $1-12$.

\section{About the authors:}

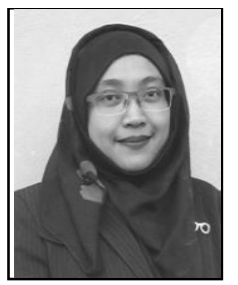

Asnidar Hanim Yusuf obtained her $\mathrm{PhD}$ in the Faculty of Economics and Muamalat, Universiti Sains Islam Malaysia in 2017.

She was born in Kangar, Perlis in Malaysia on $2^{\text {nd }}$ September 1977. She obtained her Master degree in Industrial and Technology Management from Universiti Kebangsaan Malaysia in 2011.

Before pursuing her $\mathrm{PhD}$ she was working as an engineer in various multinational companies. Concurrently she runs a Japanese Halal café in Shah Alam, a town adjacent to Kuala Lumpur. 


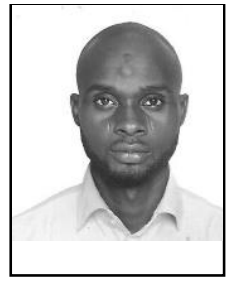

Idris Oyewale Oyelakin was born in Ibadan, Oyo state in Nigeria in August 19, 1984. He is currently an MBA student in Faculty of Economics and Muamalat, Universiti Sains Islam

Malaysia.

Idris obtain his Bachelor degree in Economics at lead City University Ibadan in 2008. After which he worked with several Consulting Firms in Nigeria as a Training Executives and Customer Relations Executive respectively before pursing his Master degree. Currently he is into various research works especially in the area of Halal products and certifications.

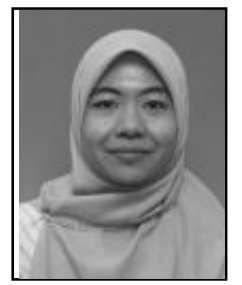

Syadiyah Abdul Shukor is a Senior Lecturer and Head Programme of Marketing (Financial Services) Programme at the Faculty of Economics and Muamalat, Universiti Sains Islam Malaysia.

She obtained her $\mathrm{PhD}$ in Marketing from Cardiff Business School. Her research interests include social influence, consumer consumption and marketing of Islamic financial services. She has published more than 20 articles including journal papers, proceedings (locally and internationally) and chapters in book.

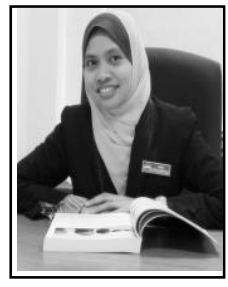

Ummi Salwa Ahmad Bustamam is a Senior Lecturer at the Faculty of Economics and Muamalat, Universiti Sains Islam Malaysia (USIM) and 
currently the Director of Centre of Student Entrepreneurship Development at USIM.

She obtained her PhD in Strategic Management from La Trobe University, Australia. Her research interests include small and medium enterprises, entrepreneurship and growth strategies. She has published more than 20 articles including journal papers, case studies, and proceedings (locally and internationally) and chapters in book. 